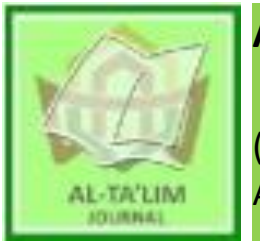

AL-TA'LIM JOURNAL, 27(3), 2020, (282-290)

(Print ISSN 1410-7546 Online ISSN 2355-7893)

Available online at http://journal.tarbiyahiainib.ac.id/index.php/attalim

\title{
Missouri Mathematics Project (MMP) Model: Encouraging the Enhancement of Reasoning Ability and the Advanced Mathematical Thinking (AMT)
}

Received: 05 ${ }^{\text {th }}$ April 2020; Revised: 06 ${ }^{\text {th }}$ April 2020; Accepted: 29th Desember 2020

Permalink/DOI: https://doi.org/10.15548/jt.v27i3.641

\section{Elfi Rahmadhani*)}

Institut Agama Islam Negeri Takengon

Aceh, Indonesia

E-mail: elfirahmadhani88@gmail.com

\section{Septia Wahyuni}

Institut Agama Islam Negeri Takengon

Aceh, Indonesia

E-mail: septiawahyuni86@gmail.com

*) Corresponding Author

\begin{abstract}
This article aims to determine the application of the model Missouri Mathematics Project (MMP) in enhancing reasoning ability and the Advanced Mathematical Thinking (AMT) of students. This research is an experimental study with a quantitative approach and Randomized Pretest-Posttest Control Group Design research design. The sample in this study were students of class XI.1 who became an experimental class by giving treatment in the form of learning model Missouri Mathematics Project (MMP) and class XI.2 students as a control class by giving treatment using conventional learning. The instruments in this study were tests in the form of pretest and posttest which were used to see the improvement of reasoning ability and the Advanced Mathematical Thinking (AMT) of students. Based on the results of the study it can be concluded that the model Missouri Mathematics Project (MMP) can improve students' reasoning abilities and the Advanced Mathematical Thinking (AMT). For reasoning ability, the average $\mathrm{N}$-gain of the experimental class is 0.76 while the $\mathrm{N}$ gain for the control class is 0.13 , while for Advanced Mathematical Thinking (AMT) the average $\mathrm{N}$-gain of the experimental class is 0.66 while the $\mathrm{N}$-gain for the control class is 0.49 .
\end{abstract}

Keywords: Advanced Mathematical Thinking (AMT); Missouri Mathematics Project (MMP); reasoning ability.

How to Cite: Rahmadhani, E., \& Wahyuni, S. (2020). Missouri Mathematics Project (MMP) Model: Encouraging the Enhancement of Reasoning Ability and the Advanced Mathematical Thinking (AMT). Al-Ta lim Journal, 27(3), 281-290. doi:https://doi.org/10.15548/jt.v27i3.641

\section{INTRODUCTION}

According to NCTM (2000) one of the school mathematics standards is reasoning. Correspondingly, one of the objectives of mathematics learning according to Minister of National Education Regulation Number. 22 (Depdiknas, 2016) is to use reasoning on patterns and traits, to manipulate mathematics in generalizing, compiling evidence or explaining mathematical ideas and statements. Reasoning is proof of mathematics offers a way to develop insight into widespread phenomena. People who reason and think analytically tend to record structural patterns and orderliness in real situations and symbolic objects (Turmudi, 2008).

Reasoning is an activity, a process, or thinking activity to draw conclusions or make a new statement that is correct based on several statements whose truth has been proven or assumed beforehand. Reasoning is also a high mindset that includes the ability to think logically and systematically. According to Utami, Mukhini, \& Jazwinarti (2014), reasoning can be interpreted as a thought process to obtain logical conclusions based on 
relevant facts. Mathematical reasoning is a brain habit as well as other habits. This must be developed consistently using a variety of contexts. Knowing reasoning and verification are fundamental aspects of mathematics (Turmudi, 2008).

According to Sumartini (2015), mathematical reasoning ability helps students to conclude and prove a statement, build new ideas, to solve problems in mathematics. Therefore, mathematical reasoning ability must always be familiarized and developed in every mathematical learning. But in reality, students' math ability, especially MAN 3 students in Central Aceh are still lacking. It can be seen from the results of observations and initial tests conducted in MAN 3, there are half of the students observed were not able to absorb the indicators of the reasoning tested. There are still students who are unable to express their ideas through answers and even if students have a picture of their ideas, they are even less able to interpret or evaluate these ideas into writing. This is also due to the lack of students' reasoning ability in using terms or structures to present ideas.

In addition to reasoning ability, Advanced Mathematical Thinking also needs to be improved. Because in general mathematics material taught at the MAN / SMA level is a material that requires creative thinking ability. Advanced Mathematical Thinking (AMT) is an ability which includes:1) the representation process, 2) the abstraction process, and 3) the relationship between representation and abstraction, 4) creative thinking and 5) mathematical proof (Tall, 2002; Sumarmo, 2011).

Some research have been conducted to improve students' mathematical reasoning abilities, from applying and using learning models to making test instruments to measure students' reasoning abilities, including research conducted by Sari, Yenni, \& Raditya (2017), Fiangga \& Sari (2017), Nurfadhilah \& MZ (2018), Manfaat \& Nurhairiyah (2013), Wibowo (2017) and Mudhiah \& Shodikin (2019). Nurfadhilah \& MZ (2018) in his research said that there are differences in mathematical reasoning abilities of students who learn to use the Contextual Teaching and Learning (CTL) learning model by using direct learning. In addition, the geometric reasoning ability of students who use problem-based learning is better than conventional learning (Mudhiah \& Shodikin, 2019).

Not only reasoning ability, some research have also been conducted to improve the ability of Advanced Mathematical Thinking (AMT), including research conducted by Suryana (2017), Suryana \& Seruni (2019), Aristika \& Darhim (2019), Mateus-nieves \& Jimenez (2020), and Sangpom, Suthisung, Kongthip, \& Inprasitha (2016). Achievement and improvement of Advanced Mathematical Thinking (AMT) abilities of students who learn with a metacognitive approach are better than students who study with ordinary learning (Hutajulu \& Minarti, 2017). Fitriani \& Nurfauziah (2020) also stated, that the use of Knisley's mathematical model affected the improvement of students' Advanced Mathematical Thinking (AMT) abilities, especially on representation ability. Based on the above it can be concluded that the application of learning models and approaches can influence students' reasoning abilities and Advanced Mathematical Thinking (AMT).

Based on some of the results of these studies it is known that the learning model used by teachers can influence students' reasoning and Advanced Mathematical Thinking (AMT) abilities. One learning model that can be used by teachers is the Missouri Mathematist Project (MMP) learning model. This learning model is one of the learning models designed to improve students' ability to understand concepts, solve problems, and solve mathematical problems so that students are finally able to arrange their own answers because of the many experiences students have in solving practice questions (Suastika \& Wisulah, 2015).

This is in line with Asiyah (2015) opinion, that the Missouri Mathematist Project (MMP) is learning that emphasizes student creativity through the development of 
concepts in controlled exercises and independent assignments. So it can be said that the Missouri Mathematist Project (MMP) is a learning model designed to help teachers effectively use exercises so that teachers are able to make students get outstanding achievements in their achievements (F.M, M, \& I, 2013). According to Jannah, Triyanto, \& Ekana (2013) the Missouri Mathematics Project (MMP) characteristic is that each student individually learns the learning material delivered by the teacher. Individual results are brought to the group for discussion and mutual discussion by group members. This model is designed to combine independence and collaboration between groups.

\section{METHOD}

This research is an experimental study with a quantitative approach, which aims to look at reasoning ability and Advanced Mathematical Thinking (AMT) through the application of the learning model Missouri Mathematics Project (MMP). The population in this study were students of class XI MAN 3 in central Aceh in the 2017/2018 school year consisting of 3 classes, namely class XI.1 with 22 students, class XI.2 with 22 students and class XI. IPS with 19 students. While the sample in this study is class XI.1 which becomes an experimental class by giving treatment in the form of Missouri Mathematics Project (MMP) learning model and class XI.2 as a control class by giving treatment using conventional learning.

This study uses a Randomized PretestPosttest Control Group Design research design. Pretest and Posttest questions are given in terms of reasoning and Advanced
Mathematical Thinking (AMT). The instrument used to collect data in this study was pretest and posttest. Pretest and posttest in this study are tests used to measure reasoning ability and Advanced Mathematical Thinking (AMT) students. Pretest was given at the first meeting to look at reasoning ability and Advanced Mathematical Thinking (AMT) students before being given treatment, while posttest was given after students were given treatment.

To see students' reasoning ability and the Advanced Mathematical Thinking (AMT), the normalized Gain formula is used as expressed by Hake (1999), the following:

Gain $(\mathrm{g})=\frac{\text { Post-test score }- \text { Pre-test score }}{\text { Ideal score }- \text { Pre-test score }}$

Whereas to answer the hypothesis in this study used $t$ test. The $\mathrm{N}$-gain interpretation is presented in table 1 below:

Table 1. Interpretation of N-Gain

\begin{tabular}{cc}
\hline Percentage & Interpretation \\
\hline $\mathrm{g}>0.7$ & High \\
$0.3<\mathrm{g}<0.7$ & Medium \\
$\mathrm{g}<0.3$ & Low \\
\hline
\end{tabular}

\section{RESULTS AND DISCUSSIONS}

This research was conducted to look at improving students' reasoning abilities and the Advanced Mathematical Thinking (AMT) by applying the learning model Missouri mathematics Project (MMP). The research data was obtained from the pretest posttest given to students. The data obtained is then processed and analyzed, the results of data processing of students' reasoning abilities can be seen in table 2 below.

Table 2. Pretest, Posttest and Gain Reasoning Abilities

\begin{tabular}{cclll}
\hline Class & \multicolumn{1}{c}{ Pretest } & \multicolumn{1}{c}{ Posttest } & Gain \\
& $\mathrm{N}$ & 22 & 22 & 22 \\
\multirow{5}{*}{ Experiment } & - & 9.54 & 20.81 & 0.76 \\
& $\mathrm{x}$ & & 6.06 & 0.01 \\
& $\mathrm{~S}^{2}$ & 30.8 & 2.46 & 0.10 \\
& $\mathrm{~S}$ & 5.20 & 22 & 22 \\
& $\mathrm{~N}$ & 22 & 11.18 & 0.13 \\
& - & 9.13 & 6.35 & 0.02 \\
& $\mathrm{x}$ & & 2.52 & 0.14 \\
\hline
\end{tabular}


Based on table 2 above it can be seen that the experimental class reasoning ability at pretest obtained $\bar{x}=9.54$ and standard deviation $(S)=5.20$, while the posttest mean value has $\bar{x}=20.81$ and standard deviation $(S)=2.46$. In the pretest the control class obtained $\bar{x}=9.13$ for reasoning ability and standard deviation $(\mathrm{S})=2.23$, while the average value of the posttest control class $\bar{x}$ $=11.18$ and standard deviation $(\mathrm{S})=2.52$. The value of $\mathrm{N}$-gain reasoning ability in the experimental class is 0.76 and, in the control, class the average $\mathrm{N}$-gain value is 0.13 . The results of data processing capabilities of Advanced Mathematical Thinking (AMT) students can be seen in table 3 below.

Table 3. Pretest, Posttest and Gain Advanced Mathematical Thinking (AMT)

\begin{tabular}{cllll}
\hline Class & & \multicolumn{1}{r}{ Pretest } & \multicolumn{1}{r}{ Posttest } & \multicolumn{1}{c}{ Gain } \\
\hline \multirow{5}{*}{ Experiment } & $\mathrm{N}$ & 22 & 22 & 22 \\
& $\bar{x}$ & 3.77 & 16.68 & 0.66 \\
& $\mathrm{~S}^{2}$ & 0.76 & 5.18 & 0.01 \\
& $\mathrm{~S}$ & 0.87 & 2.28 & 0.11 \\
\hline \multirow{5}{*}{ Control } & $\mathrm{N}$ & 22 & 22 & 22 \\
& $\bar{x}$ & 3.36 & 12.86 & 0.49 \\
& $\mathrm{~S}^{2}$ & 1.67 & 9.36 & 0.02 \\
& $\mathrm{~S}$ & 1.29 & 3.06 & 0.13 \\
\hline
\end{tabular}

Based on table 3 above, it can be seen that the ability of Advanced Mathematical Thinking (AMT) for experimental class students to pretest is obtained $\bar{x}=9.54$ and standard deviation $(S)=5.20$, while the posttest mean value has $\bar{x}=20.81$ and standard deviation $(S)=2.46$. In the pretest of the control class the ability of Advanced Mathematical Thinking (AMT) was obtained with $\bar{x}=9.13$ and standard deviation $(\mathrm{S})=$ 2.23, while the average value of the posttest of the control class $\bar{x}=11.18$ and standard deviation $(\mathrm{S})=2.52$. The $\mathrm{N}$-gain value for Advanced Mathematical Thinking (AMT) capability in the experimental class is 0.76 and, in the control, class the average $\mathrm{N}$-gain value is 0.13 .

The data which has been obtained was then tested for normality and homogeneity of the variance. Data normality test is done using Chi Square test with normality test criteria is if $\chi^{2}$ count $\geq \chi^{2}$ table the data is not normally distributed. Based on the calculations that have been carried out on the experimental class, it is found that for reasoning ability values $\chi_{\text {count }}^{2}=171.2603$ and $\chi_{\text {table }}^{2}=$ 32.671 or $171.2603>32.671$ so that it can be concluded that the data contained in the experimental class for reasoning abilities are not normally distributed. Whereas in the control class, after the calculation is obtained the value $\chi_{\text {count }}^{2}=77.01515$ and $\chi_{\text {table }}^{2}=$ 32.671 or $77.01515>32.671$ so that it can be concluded that the data contained in the control class for reasoning ability is not normally distributed. While for the ability of Advanced Mathematical Thinking (AMT) in the experimental class the value is $\chi^{2}$ count $=$ 13.0535 and $\chi_{\text {table }}^{2}=32.671$ or 13.0535 $<32.671$ so it can be concluded that the data contained in the experimental class is normally distributed. Whereas in the control class, after the calculation is obtained the value of $\chi_{\text {count }}^{2}=15.9767$ and $\chi_{\text {table }}^{2}=$ 32.671 or $15.9767<32.671$ so it can be concluded that the data contained in the control class for Advanced Mathematical Thinking (AMT) capabilities are normally distributed. For more details, seen table 4 below. 
Table 4. Normality Test Reasoning Ability and Advanced Mathematical Thinking (AMT)

\begin{tabular}{ccccc}
\hline Ability & Class & $\chi^{2}$ count & $\chi^{2}$ table & Explanation \\
\hline Reasoning & Eksperiment & 171.2603 & 32.671 & Abnormal \\
Advanced & Control & 77.01515 & 32.671 & Abnormal \\
Mathematical & Eksperiment & 13.0535 & 32.671 & Normal \\
Thinking (AMT) & Control & 15.9767 & 32.671 & Normal \\
\hline
\end{tabular}

Because the $\mathrm{N}$-gain data for the second reasoning ability of the sample class is not normal, then a non-parametric test is performed using the Mann Whitney test with the help of SPSS. As for the ability of Advanced Mathematical Thinking (AMT) because the N-gain data of the two sample classes were normally distributed, a t-test was conducted to see the differences in the improvement of mathematical reasoning abilities and the Advanced Mathematical Thinking (AMT) students who used the learning model Missouri mathematics Project (MMP). Because the N-gain data of Advanced Mathematical Thinking (AMT) capability is normally distributed, a homogeneity test is performed to see whether the two sample classes have the same variance using the Levene test with the help of SPSS using 0.05 significant values, as shown in the table 5 below.
Table 5. Homogeneity Test Advanced Mathematical Thinking (AMT)

\begin{tabular}{cccc}
\hline $\begin{array}{c}\text { Levene } \\
\text { Statistics }\end{array}$ & df1 & df2 & Sig. \\
\hline 0.427 & 1 & 42 & 0.517 \\
\hline
\end{tabular}

From table 5 above, it is known that the significance value of increasing the ability of Advanced Mathematical Thinking (AMT) students is 0.517 , or greater than the significant level used, namely 0.517>0.05. This means that increasing the ability of Advanced Mathematical Thinking (AMT) students in the sample class has the same or homogeneous variance. After testing the normality and homogeneity of the data on the enhancement of reasoning ability and the Advanced Mathematical Thinking (AMT) of students, then the hypothesis was tested as shown in table 6 below.

Table 6. Improvement of Reasoning Ability and Advanced Mathematical Thinking (AMT)

\begin{tabular}{cllcccc}
\hline Ability & Class & $\mathrm{N}$ & Median & t count & df & Sig. \\
\hline \multirow{2}{*}{ Reasoning } & Eksperiment & 22 & 0.76 & \multirow{2}{*}{5.687} & \multirow{2}{*}{42} & \multirow{2}{*}{0.000} \\
Advanced & Control & 22 & 0.13 & & & \\
Mathematical & Cksperiment & 22 & 0.66 & & \multirow{2}{*}{4.844} & 0.000 \\
Thinking (AMT) & & 22 & 0.49 & & & \\
\hline
\end{tabular}

Based on table 6 above, it is known that for reasoning ability the $t$ count value obtained is 5,687 and the sig value. (2-tailed) of $0.000<0.05$, then according to the basis of decision-making in the Mann Whitney test it can be concluded that Ho is rejected, meaning that there are differences in the improvement of students' mathematical reasoning ability toward the learning model Missouri mathematics Project (MMP). As for the ability of Advanced Mathematical Thinking (AMT) the calculated t value is 4,844 and the sig value. (2-tailed) of $0.000<0.05$, it can be concluded that Ho is rejected, meaning that there is a difference in the increase in the ability of Advanced Mathematical Thinking (AMT) students to the learning model Missouri mathematics Project (MMP).

Based on data processing and observation during the learning process it is known that there are significant differences in the ability of reasoning and Advanced Mathematical Thinking (AMT) students who 
learn using the Missouri Mathematist Project (MMP) and conventional. Students who were taught with the Missouri Mathematist Project (MMP) learning model have better reasoning and Advanced Mathematical Thinking (AMT) skills compared to students who are taught with conventional learning. This is because students are accustomed to reason when confronted with a problem. In line with Sari, Yenni, \& Raditya (2017) opinion which says that when students are given the opportunity to use their reasoning in guessing solutions or solutions to a given problem, students will more easily understand the concept and can solve the problem with their own ways and experiences which will indirectly improve results study them.

In addition, according to Aristika \& Darhim (2019) and Herlina (2015) there are several benefits that can be obtained when we develop students' Advanced Mathematical Thinking (AMT) abilities, including 1) in conveying ideas, students can do them verbally, symbols, tables, graphs and diagrams, 2) students can find relationships and relationships between branches of mathematics, 3) can trigger allegations in the branch of mathematics associated with knowing the results in other branches, 4) in proving the results in a branch can be used methods and techniques from other branches, 5) can find new ideas in problem solving and 6) can understand concepts and build evidence.

In learning to use the Missouri Mathematist Project (MMP) students are more active, especially in the discovery of concepts and exercises conducted in groups. By learning in groups students are accustomed to expressing their opinions, consulting and correcting mistakes made, so that they become more confident and can optimize their potential. Aristika \& Darhim (2019) and Rasmussen, Zandieh, \& King (2005) also said that cooperative learning models and strategies have a great influence on students' abilities when compared to other models and strategies, especially on Advanced Mathematical Thinking (AMT) abilities. The right learning strategies and models can improve students' Advanced Mathematical Thinking (AMT) abilities.

The improvement of students' reasoning abilities referred to in this study is the ability or capability to perform an activity, process or an activity of thinking systematically to draw conclusions.

\section{The Validity of the Argument and Draw Conclusions}

The validity of the argument and drawing conclusions includes the ability of students to provide answers using a predetermined formula. Students are able to investigate the correctness of the argument. Problem instruments that measure this aspect one of them are questions 5 and 3. Based on an analysis of student answer sheets it appears that they have been able to write down information that is known. In the experimental class students have been able to calculate the values correctly. This shows that the experimental class students' mathematical reasoning ability on the validity of the argument has developed well. This is because in the Missouri Mathematist Project (MMP) model students are accustomed to dare to make decisions from the activities carried out (Yuliani, Praja, \& Noto, 2018).

Whereas in the control class students, most students still cannot explain and have not been able to do the calculations correctly, the students' answers show that this aspect has not been well achieved. Even though students have written answers but there are still some who are lacking in stating the information contained in the questions properly or students have not been able to do the calculations correctly and completely.

\section{Make a Picture}

Making pictures includes the ability of students to provide answers using ability in drawing. When drawing students must be able to see the numbers correctly, so they can draw correctly and according to the desired results. Problem instruments that measure this aspect one of them is question No. 4. From the students 'answers it appears that they have 
been able to write down the known information, this shows that the experimental class students' mathematical reasoning ability on the drawing indicator has been well developed. This is because in the Missouri Mathematist Project (MMP) model especially at the development stage, students are directed to be able to draw sketches and write things that are needed during learning (Yuliani et al., 2018).

Whereas in the control class students, most of the students still cannot draw from table form to picture. It can be seen from the students' answers that have not been achieved well, because students do not understand in looking at tables. This shows that this aspect has not been well achieved. Even though students have been able to describe the answer in the form of tables into the histogram but not as expected. At the time of drawing students have not been able to state the information contained in the problem properly or students have not been able to describe the shape of the histogram and polygon correctly and completely.

\section{Asking Allegations}

In asking for allegations students were asked to draw a line diagram and suspect when the highest absences occurred. Asking allegations when students are given a question in writing and students must pay attention to the questions clearly and understand. In proposing allegations includes the ability of students to provide answers using their own language. Problem instruments that measure this aspect, one of which is questions 1 and 2. In the experimental class the students have been able to answer the questions well, this shows that the experimental class students' mathematical reasoning ability to put forward allegations has been well developed. Whereas in the control class students, most of the students still could not explain or submit allegations in the form of drawings to writing, student answers showed that this aspect had not been well achieved. Because students have not been able to describe and predict when the highest absences occur. Although students have been able to describe their answers, but there are still some who are lacking, but students have not been able to state the information contained in the problem properly or students have not been able to issue ideas in the indicators to submit allegations correctly and completely.

Increase the ability of Advanced Mathematical Thinking (AMT) students seen in this study is the process of representation, the process of abstraction, and linking representations and abstractions.

\section{Representation}

Representation is used in communicating mathematics by using tables, images, graphics, expressions or mathematical notations and writing in their own language. From the analysis of students 'answer sheets, it can be seen that students have been able to write down the problem solving steps in their own words, restating the information obtained from the questions into tables and graphs and this can be seen from the students' answers to problem number 4 . Students have been accustomed to finding and applying the ideas they have in solving problems in groups, which causes them to be optimal in completing exercises and not to repeat the same mistakes in subsequent exercises (Pratiwi, Astawa, \& Mahayukti, 2019).

\section{Abstraction}

According to Tall (2002), abstraction is the process of describing certain situations into a concept that can be thought through a construction. In this process students must be able to identify what techniques can be done to solve the given problem. From the tests given students have been able to manipulate mathematical objects using mathematical symbols. Students have also been able to use their previous experience or knowledge in solving the given problem.

\section{Linking Representations and Abstractions}

In accordance with the opinion of Ferrari (2003) that there is a close relationship 
between representation and abstraction, where representation has an important role in the process of generalization, decontextualization, and reification which are part of a more complex abstraction process. For example, students have been able to generalize on problem number 3. To obtain the density function of the cumulative distribution function, the function is derived first. Although not yet perfect, but the ability to connect representations and abstractions of students has begun to increase compared to when they were not treated using the model Missouri Mathematist Project (MMP). In accordance with Pujiastuti, Suyitno, \& Sugiman (2020) opinion which says that the teacher's role in learning is very important, the teacher is expected to be able to explore students' mathematical thinking processes, one of which is by providing different problems, making solutions and providing assistance to students through systematic and measurable stages, so that the ability Advanced Mathematical Thinking (AMT) students can develop well.

\section{CONCLUSIONS AND RECOMMENDATIONS}

Based on the results of data processing and analysis previously stated, the conclusion is that the improvement of students' mathematical reasoning abilities that were treated by using the learning model Missouri Mathematist Project (MMP) better than students who were treated using conventional learning. It can be seen from the average Ngain that the experimental class is 0.76 while the $\mathrm{N}$-gain of the control class is 0.13 .

Increasing the ability of Advanced Mathematical Thinking (AMT) students who were treated using th learning model Missouri Mathematist Project (MMP) better than students who were treated using conventional learning. It can be seen from the average Ngain that the experimental class is 0.66 while the control class N-gain is 0.49 .

This research provides certain teaching model for the teachers. They possibly could use AMT and MMP in helping the students to increase their mathematical ability. Thus, the mathematical teacher should always find possible strategies, method, approaches in order to improve the quality of education.

\section{REFERENCES}

Aristika, A., \& Darhim. (2019). MetaAnalysis the Effect of Learning Strategies on Ability Advanced Mathematical Thinking Students. International Conference on Mathematics and Science Education, 4, 110-115.

Asiyah, R. (2015). Pembelajaran Missouri Mathematic Project (MMP) Pada Pokok Bahasan Garis dan Sudut untuk Meningkatkan Pemahaman Siswa Kelas VII F SMPN 1 Sumbergempol Tulungagung. Jurnal PINUS, 1(3). https://doi.org/10.1017/CBO9781107415 324.004

Depdiknas. (2016). Permendiknas Nomor 22 Tahun 2016. Jakarta: Depdiknas

F.M, A., M, C., \& I, J. (2013). Keefektifan Model Pembelajaran Generatif dan MMP Terhadap Kemampuan Pemecahan Masalah. Jurnal Kreano, 4(2), 131-137.

Ferrari, P. L. (2003). Abstraction in mathematics. The Royal Society, (June), 1225-1230. https://doi.org/10.1098/rstb.2003.1316

Fiangga, S., \& Sari, Y. M. (2017). Analisis Generalisabilitas Multi Faset pada Instrumen Penalaran Matematika SMP. Jurnal Elemen, 3(2), 118-129. https://doi.org/10.29408/jel.v3i2.398

Fitriani, N., \& Nurfauziah, P. (2020). Meningkatkan Kemampuan Advanced Mathematical Thinking dengan Menggunakan Model Pembelajaran Matematika Knisley Pada Mata Kuliah Trigonometri. JPMI - Jurnal Pembelajaran Matematika Inovatif, 3(1), 69-80.

https://doi.org/10.22460/jpmi.v3i1.p6980 
Herlina, E. (2015). Advanced Mathematical Thinking and the Way to Enhance IT. Journal of Education and Practice, 6(5), 79-89.

Hutajulu, M., \& Minarti, E. D. (2017). Meningkatkan Kemampuan Advanced Mathematical Thinking dan Habits of Mind Mahasiswa Melalui Pendekatan Keterampilan Metakognitif. JES-MAT, 3(2), 177-194.

Jannah, M., Triyanto, \& Ekana, H. (2013). Penerapan Model Missouri Mathematic Project (MMP) Untuk Meningkatkan Pemahaman dan Sikap Positif Siswa Pada Materi Fungsi. Jurnal Pendidikan Matematika Solusi, 1(1), 61-66.

Manfaat, B., \& Nurhairiyah, S. (2013). Pengembangan Instrumen Tes Untuk Mengukur Kemampuan Penalaran Statistik Mahasiswa Tadris Matematika. Eduma: Mathematics Education Learning and Teaching, 2(2). https://doi.org/10.24235/eduma.v2i2.41

Mateus-nieves, E., \& Jimenez, C. A. R. (2020). Mathematical Generalization from the Articulation of Advanced Mathematical Thinking and Knot Theory. Acta Scientiae, 22(3), 65-81. https://doi.org/10.17648/acta.scientiae.56 67

Mudhiah, S., \& Shodikin, A. (2019). Pengaruh Model Pembelajaran Berbasis Masalah Terhadap Kemampuan Pemahaman Konsep dan Penalaran Geometris Siswa. Jurnal Elemen, 5(1), 43-53. https://doi.org/10.29408/jel.v5i1.974

NCTM. (2000). Principle and Standarts for School Mathematics

Nurfadhilah, N., \& MZ, Z. A. (2018). Kemampuan Penalaran Matematis Melalui Pembelajaran Contextual Teaching and Learning (CTL) Pada Siswa SMP. Jurnal Elemen, 4(2), 171182.

https://doi.org/10.29408/jel.v4i2.714
Pratiwi, N. P. K. A., Astawa, I. W. P., \& Mahayukti, G. A. (2019). Missouri Mathematics Project (MMP), Pemahaman Konsep Matematika, dan Kepercayaan Diri Siswa. Jurnal Elemen, 5(2), 178-189. https://doi.org/10.29408/jel.v5i2.1317

Pujiastuti, E., Suyitno, A., \& Sugiman, S. (2020). Using of Divergent Problems Based on Teacher Scaffolding Levels to Grow of Advanced Mathematical Thinking of Senior High School Students. Journal of Physics: Conference Series, 1567(022093). https://doi.org/10.1088/17426596/1567/2/022093

Rasmussen, C., Zandieh, M., \& King, K. (2005). Advancing Mathematical Activity: a Practice-Oriented View of Advanced Mathematical Thinking. Mathematical Thinking and Learning, 7(1), 51-73. https://doi.org/10.1207/s15327833mt107 01

Sangpom, W., Suthisung, N., Kongthip, Y., \& Inprasitha, M. (2016). Advanced Mathematical Thinking and Students , Mathematical Learning : Reflection from Students, Problem-Solving in Mathematics Classroom. 5(3), 72-82. https://doi.org/10.5539/jel.v5n3p72

Sari, I. P., Yenni, Y., \& Raditya, A. (2017). Pengaruh Pendekatan Pembelajaran Contextual Teaching and Learning (CTL) Terhadap Kemampuan Penalaran Matematis Siswa SMP. Prima: Jurnal Pendidikan Matematika, 1(1), 19-32. https://doi.org/10.31000/prima.v1i1.251

Suastika, I. K., \& Wisulah. (2015). Pendekatan Missouri Mathematics Project Berorientasi Pakemi Dalam Upaya Memotivasi Kreativitas Mahasiswa Prodi PGSD Universitas Kanjuruhan Malang. Jurnal Inspiraasi Pendidikan Universitas Kanjuruhan Malang, 5(2), 722-732. https://doi.org/https://doi.org/10.21067/ji p.v5i2.811 
Sumarmo. (2011). Advanced Mathematical Thinking and Habits of Mind Mahasiswa. Hand Out Perkuliahan. PPS UPI Bandung: tidak diterbitkan

Sumartini, T. S. (2015). Peningkatan Kemampuan Penalaran Matematis Siswa Melalui Pembelajaran Berbasis Masalah. Mosharafa Jurnal Pendidikan Matematika, 5(1), 1-10.

Suryana, A. (2017). Association Between The Students' Self-Renewal Capacity and Advanced Mathematical Thinking. Prosiding Seminar Nasional Integrasi Matematika Dan Nilai Islami, 1(1), 5864.

Suryana, A., \& Seruni. (2019). Advanced Mathematical Thinking dalam Pembelajaran Matematika Tingkat Lanjut. Jkpm - Jurnal Kajian Pendidikan Matematika, 5(1), 15-28.

Tall, D. (2002). Advanced Mathematical Thinking. Boston: Kluwer

Turmudi. (2008). Landasan Filsafat Dan Teori Pembelajaran Matematika
(Berparadigma Eksploratif dan Investigasi). Jakarta: Leuser Cita Pustaka

Utami, N., Mukhini, \& Jazwinarti. (2014). Kemampuan Penalaran Matematis Siswa Kelas XI IPA SMAN 2 Painan Melalui Penerapan Pembelajaran Think Pair Square. Jurnal Pendidikan Matematika, Vol 3(1), 7-12.

Wibowo, A. (2017). Pengaruh Pendekatan Pembelajaran Matematika Realistik dan Saintifik terhadap Prestasi Belajar, Kemampuan Penalaran Matematis dan Minat Belajar. Jurnal Riset Pendidikan Matematika, 4(1), 1-10. https://doi.org/10.21831/jrpm.v4i1.1006 6

Yuliani, R., Praja, E. S., \& Noto, M. S. (2018). Pengaruh Model Pembelajaran Missouri Mathematics Project Terhadap Kemampuan Koneksi Matematis dan Kemandirian Belajar Siswa SMP. Jurnal Elemen, 4(2), 131-144. https://doi.org/10.29408/jel.v4i2.478 